\title{
PRIKAZI GRADSKE VLASTELE U ROMANU POSLJEDNJI STIPANČIĆI VJENCESLAVA NOVAKA I NJIHOVA POVIJESNA UTEMELJENOST
}

\author{
Andrea Roknić Bežanić \\ Filozofski fakultet u Rijeci \\ Odsjek za povijest \\ Sveučilišna avenija 4 \\ HR 51000 Rijeka \\ roknicbezanicandrea@gmail.com \\ Bruno Raguž \\ Hrvatskih domobrana 19 \\ HR 44000 Sisak \\ brunoraguz@gmail.com
}

UDK: 929.7(497.5Senj)(093)

821.163.42.09Novak, V.

Izvorni znanstveni članak

Ur.: 2020-6-1

Rad kao polazište svoje historiografske analize uzima opise gradskih plemićkih obitelji iz romana Posljednji Stipančići Vjenceslava Novaka. Nakon što se iznese kratki povijesni okvir, koji se upotpunjuje s opisima što ih daje V. Novak, rad se kratko osvrće i na pitanje borbe za hrvatski jezik, no najvećim se dijelom bavi analizom povijesnog utemeljenja likova i radnje korištenjem egzaktnih i preciznih navoda iz stvarne povijesne zbilje. Na kraju se donose i Katastarski upisnici čestica iz Državnog arhiva u Zagrebu koji se također uspoređuju s navodima iznesenima u djelu.

Ključne riječi: plemstvo, Senj, 19. st., Vjenceslav Novak, Stipančići

\section{Uvod}

Roman Posljednji Stipančići objavljen je 1899. godine. U njemu Vjenceslav Novak gotovo kirurškom preciznošću prikazuje senjsku sredinu u trenucima kada se svijet, dotad dobro poznat ondašnjem plemstvu, vrlo brzo mijenja. Razdoblje je to kada stoljetne plemićke obitelji nestaju ili se pretvaraju u građanske obitelji. Roman predstavlja jedno od najznačajnijih i najprepoznatljivijih djela hrvatske književnosti u području povijesnoga romana, stoga je logično zaključiti kako je pisac u njemu težio prikazivanju točnih podataka o akterima koje navodi kao nositelje navedenih događaja i procesa u Senju tog vremena. 
Rad stoga želi predstaviti prikaze V. Novaka o životu i propadanju senjske vlastele, način na koji sam pisac promišlja povijesnu zbilju toga vremena te kako opisuje pojedine povijesne ličnosti. Ovaj rad dodatno diskutira o takvim tezama koristeći informacije koje se mogu pronaći u arhivskoj građi i dosad objavljenoj literaturi, a odgovara i na pitanje jesu li likovi navedeni kao "posljednji" Stipančići uistinu zadnji pripadnici poznate loze te koliko se drugi likovi i opisi podudaraju s današnjim saznanjima o povijesti Senja toga vremena. Dakako, ovaj rad nije ni književna studija ni analiza, već književni predložak uzima kao polazište svoje historiografske analize.

Kao glavni izvor u proučavanju tematike korištena je građa Hrvatskog državnog arhiva u Zagrebu, u prvom redu matične, tj. crkvene knjige toga vremena. Sekundarno se istraživanje oslanja na Katastarske upisnice, uz korištenje sustava Family search ${ }^{1}$ i prethodno objavljenih radova, a na koncu, naravno, i literarnog predloška.

\section{Metodologija rada}

Osnovno polazište za analizu i rasprave književno je djelo koje će poslužiti za promatranja i usporedbe na nekoliko razina. Prva razina s kojom će se književni predložak komparirati su dosad već poznate i objavljene činjenice o povijesti Senja toga razdoblja. No, takav postupak doprinio bi tek ponovnoj sintezi već poznatih činjenica, stoga se rad dalje razvija koristeći arhivsko gradivo, koje treba podijeliti u dvije grupe. Prva je ona koja se odnosi na matične knjige rođenih koje je vodila crkvena jurisdikcija, a one će poslužiti kao dokumentacijska osnova za promišljanja o povijesnoj utemeljenosti likova na način da će se egzaktno imenovati tko je i kada rođen i živio u Senju u razdoblju radnje romana - nakon života "posljednjih" Stipančića. Druga grupa dokumenata arhivskog gradiva predstavlja Katastarske upisnice, od kojih je odabrana godina 1870. kao najbliža dokumentirana nakon kraja radnje romana. Takvim pristupom propituje se postojanje posjeda obitelji koje su prethodno pronađene arhivskim istraživanjem.

${ }^{1}$ Family search je online alat pomoću kojega je moguće pretraživati rodoslovna stabla i genealogijske historije obitelji širom svijeta. Navedeni alat temelji se na samostalnom upisivanju pripadnika obitelji, ali i na dostupnom arhivskom gradivu kojega se može pretraživati putem alata te se navedena platforma često koristi prilikom arhivskog pretraživanja. Važno je napomenuti da se u radu alat koristi samo kako bi se došlo do arhivskog gradiva te ono ne predstavlja dokumentacijsku osnovu. 
Kratki uvod u povijesnu zbilju Senja i segmenti opisa Vjenceslava Novaka

Grad Senj, iako nevelik, prepoznatljiv je po svojoj bogatoj kulturnopovijesnoj baštini. Kratki povijesni okvir relevantan za sadržaj i analizu u nastavku poslužit će kao kontekst istraživanju.

Krajem 18. i početkom 19. st., kada više nije postojala izražena opasnost od Osmanlija za Senj i njegovu okolicu, započinje mirnije i prosperitetnije vrijeme. Tako je povezivanjem Senja Jozefinskom cestom (1779.) s Karlovcem otpočeo osjetniji gospodarski rast. Došlo je do obnove trgovine, a Senj je svoj uspješni gospodarski uspon u nadolazećem vremenu vezao prvenstveno uz pomorstvo i trgovinu. Senjska luka postala je glavna izvozna luka, glavno mjesto kroz koje se vršio uvoz soli, ali i znatniji izvoz žita i drva. ${ }^{2}$ Takva povoljna gospodarska situacija zrcalila se i na društveno-kulturni život u gradu i okolici. Tada se u grad doseljava nova radna snaga, ali i brojni poduzetnici i njihove obitelji. Osnivaju se trgovačka i brodograđevna društva te trgovačka i obrtnička komora. Izvode se građevinski i infrastrukturni radovi, što mijenja samu vizuru grada, a Senj postaje jedan od kulturnih centara tadašnje Hrvatske. Upravo u to vrijeme grade se neke od najistaknutijih senjskih palača i zgrada. ${ }^{3}$

No, izgradnjom željezničke pruge Zagreb - Rijeka 1873., došlo je do zaobilaženja Senja. Takva situacija zadala je težak udarac daljnjem razvoju gospodarstva jer je sav promet, koji je do tada išao preko Senja, bio usmjeren na Rijeku. Stoga Senj u godinama koje slijede doživljava gospodarsko propadanje. Takve prilike dodatno su ubrzale i pospješile već započet proces propadanja viših građanskih obitelji i plemstva. Plemstvo je kao privilegirani stalež bilo važna politička i društvena sastavnica u dugom razdoblju hrvatske prošlosti. No, tijekom gotovo čitavoga 19. st., a posebno njegova kraja, dolazi do dekadencije i propadanja. Taj proces zahvatio je i senjske plemićke obitelji.Takve okolnosti, između ostaloga, najbolje su prikazane realističnim književnim predloškom toga vremena što je vrlo zorno u svojim djelima uradio upravo Novak.

\section{Povijesni okvir romana}

Kako bi se što točnije mogli analizirati opisi što ih je ponudio Novak, nužno je, a i povjesničarski posve opravdano, odrediti vremenski okvir

${ }^{2}$ SENJ, Povijest Grada, URL: https://www.senj.hr/povijest-grada/ (2020-7-6)

3 SENJ, Hrvatska online enciklopedija, URL: https://www.enciklopedija.hr/natuknica. aspx?ID=55414 (2019-12-19) 
u kojem je radnja romana smještena. Najranija točka u vremenu, koja se ujedno može pronaći i u stvarnoj faktografskoj povijesti, gradnja je Palače Domazetović, o kojoj pisac kaže: "Tu - bog zna po koji put obnovljenu slogu, a i još jednu vijest koja je građanske grudi s velikim ponosom što se rađa u duši Čovjeka pobjednika nadimala, odluče oni proslaviti sjajnim plesom u dvorani novosagrađene kuće Domazetovićeve."4 Navedena palača sagrađena je 1744. godine, a u Senju je poznata i pod nazivom Ferajna. ${ }^{5}$ Sljedeći podatak koji Novak navodi je da je gradski statut napisan 1755 . No, prema poznatim izvorima, Statut grada nastao je dvije godine kasnije (1757.6), iz čega je razvidno da je autor poznavao povijesnu zbilju, no ipak su mu se potkrala manja odstupanja.

Nakon toga, Novak donosi biografske podatke o jednom od likova - o Jurju Stipančiću. Pored ostaloga, navodi da se rodio 1806., što dodatno pomaže odrediti povijesni okvir. ${ }^{7}$ Jasno je kako se u danim povijesnim okolnostima dio senjskih građanskih obitelji i intelektualaca idejno naklonio preporodnoj ideji i oblikovanju nacionalne ideologije. Potvrdu o tome također pronalazimo i kod Novaka. Tako on značajni dio opisa posvećuje preporodnim težnjama jednog od svojih glavnih likova te između ostalog navodi "On je brzo shvatio pokret što ga je u Zagrebu uz grofa Draškovića pripravljao Gaj."8 Iz navedenog citata shvatljivo je da se radi o razdoblju hrvatskog narodnog preporoda koji se odvijao u prvoj polovici 19. st. kada su Janko Drašković i Ljudevit Gaj bili izrazito aktivni, što dodatno utvrđuje položaj roman u vremenu povijesne zbilje te znanje autora o danom povijesnom trenutku.Također je i pitanju borbe za hrvatski jezik, kao jednom od ključnih stavki hrvatskog preporoda, autor posvetio značajan prostor, o čemu će se govoriti u nastavku rada.

Iz svega spomenutog, može se zaključiti kako autor navodi podatke počevši od sredine 18. stoljeća, kada se spominje izgradnja palača, ali radnju gradi i kroz prvu polovicu 19. st. kada daje podatke o rođenju Jurja Stipančića. U prilog tomu idu i druge odrednice poput hrvatskog narodnog preporoda, što povijesno odgovara razdoblju u kojem su se počele događati značajne promjene u društvenim odnosima, koje su vjerojatno i najbolnije osjetile plemićke obitelji. Upravo su one tijekom društvenih previranja izgubile najviše u pogledu društvenog statusa, ali i materijalno-pravnih i drugih

${ }^{4}$ V. NOVAK, 1999, 31.

${ }^{5}$ E. LJUBOVIĆ, 2009, 199-208.

${ }^{6}$ Ž. BARTULOVIĆ, 2013, 400.

${ }^{7}$ V. NOVAK, 1999, 14.

${ }^{8}$ V. NOVAK, 1999, 37. 
prava. S ocjenom da se radnja smješta u prvu polovicu 19. st. slažu se i neki povjesničari književnosti. ${ }^{9}$

\section{Život plemićkih obitelji}

Uvid u život plemićkih obitelji dobiva se kada Novak na nekoliko mjesta navodi opise interijera kuća, ali i načina plemićkog života. Govoreći o interijeru i uređenju plemenitaških domova, autor govori o kućama prepunima starinskog i glomaznog namještaja. Takvi opisi dodatno produbljuju dojam kako se plemstvo oslanja na stara, minula vremena: "Te su sobe bile upravo nakrcane svakojakim pokućstvom. Osobito se isticahu izrazom dosadne i tupe nadutosti ogromni starinski ormari uz krevete na kojima bi mogla četvorica uporedo ležati; onda masivni stolovi sa teškim stolicama; stolice s bogatom rezbarijom, a ploče stolova s umetnutim arabeskama i ornamentima od žutog, bijelog i crnog drva. Po zidovima visile su slike sa tamnožutim, čađavim licima neprirodnog $\mathrm{i}$ istog ukočenog izražaja na svim slikama". ${ }^{10}$ Nekadašnji raskošni način života pisac jasno naznačuje opisima poput onoga kada govori o bogatoj proslavi izvan grada povodom rođenja Jurja Stipančića: "(...) Stipančića da se velika obiteljska slava obavi u njegovom vinogradu na sjeveroistočnoj strani nedaleko od gradskoga zida. Da se ne moraju visoki i odlični gosti niti onih pedeset koraka sa glavne ceste do vinograda uspinjati, dao je utrti cestu do same sredine vinograda gdje je bio zbijen šator za mnogobrojne pozvanike."11

Zanimljiv je opis koji Novak donosi govoreći o Gertrudi, starijoj pripadnici plemstva koja je bila jako uznemirena vidjevši da obogaćene građanske obitelji koriste predmete koji su u prvom redu bili statusni simboli plemićkih obitelji. Jasno se ovdje zrcali problem predrasuda i stava kod pripadnika plemstva koji su određene statusne simbole željeli zadržati za sebe. Primjer za to je srebrni lončić za vodu: "Kćeri starih patricija i plemića senjskih vukle bi vodu iz bunara srebrnim kotlićem na srebrnom lancu... Sama sam vidjela takovih srebrnih kotlića i lanaca i kod prostih građanskih obitelji koje nijesu potjecale od patricija ni od plemića". ${ }^{12}$ Iz takvog opisa jasna je tendencija da se prikaže antagonizam između umiruće plemićke i "novorođene" bogate građanske klase iako, kako je i poznato, ni sami Stipančići nisu bili plemenitaškog roda (u čemu će upravo neki vidjeti

\footnotetext{
${ }^{9}$ D. DURIĆ, 2011, 20.

${ }^{10}$ V. NOVAK, 1999, 23.

${ }^{11}$ V. NOVAK, 1999, 14.

${ }^{12} \mathrm{~V}$. NOVAK, 1999, 10.
} 
frustraciju zbog želje da se svrstaju u stalež kojemu nisu pripadali ${ }^{13}$ ). Plemićke obitelji prikazane su i kao izrazito tradicionalne i konzervativne, kao što je to slučaj sa starim Stipančićem jer "... On bi tada dokazivao da se od žene ne može više zahtijevati nego da bude dobra domaćica i vjerna supruga koja umije razumjeti svoga muža i tako mu ugoditi."14 Takvi patrijarhalni odnosi koji su proizašli iz staleških odrednica će, prema mišljenju nekih povjesničara književnosti, "koštati" starog Stipančića. ${ }^{15}$ Osim što su bile tradicionalne, plemićke obitelji odisale su i duhom staroga vremena ne samo u namještaju i uređenju kuća već i u običajima kao što je to bio dvoboj Wintera i Stipančića. Način je to da se prikaže zaostalost misli jer su dvoboji u 19. st. u najvećoj mjeri u Europi bili zabranjeni te ih je velika većina smatrala antagonizmom prošloga vremena, koji su još prakticirali tek neki neposlušni vojnički časnici.

\section{Pitanje borbe za hrvatski jezik}

Važan dio u opisima života i mentaliteta senjskih plemića svakako zauzima i hrvatski narodni preporod, točnije borba za pozicioniranje hrvatskog jezika. Tako se u djelu spominju poznati povijesni protagonisti poput Draškovića i Gaja, ali Novak navodi i kako su senjski plemići "brzo shvatili pokret" ili pak kako su određeni plemenitaši shvatili kako je pogašena "luč narodne svijesti". ${ }^{16}$

S druge strane, pisac želi naglasiti da se ipak određenom dijelu aristokracije nije svidjela borba za narodni jezik. Najočitiji primjer Novak navodi prije samoga završetka djela, kada spominje mladoga postolara Gašpara koji je kupio kuću Stipančića te je fućkao melodiju poznate budnice Još Horvatska ni propala, no ona se nikada nije probila do, kako Novak kaže, "gnijezda" stare aristokracije. Dojam otuđenosti aristokracije od ideje narodnog pokreta potkrepljuje i navodom kako "(...)hrvatski se javno u otmjenim krugovima govorilo onda samo u trgovačkom poslu (...) Isključivom pravu hrvatske materinske riječi bilo je ipak sačuvano mjesto u obiteljima građana."17 Jasno je stoga da autor upravo sloj građanstva vidi kao element očuvanja hrvatskog jezika u prošlosti, a vjerojatno i kao faktor njegova razvoja u budućnosti. Budućnost hrvatskog jezika jasno se mogla osloniti

\footnotetext{
${ }^{13}$ D. DURIĆ, 2011, 22.

${ }^{14}$ V. NOVAK, 1999, 29.

${ }^{15}$ D. DURIĆ, 2011, 22.

${ }^{16} \mathrm{~V}$. NOVAK, $1999,37$.

${ }^{17}$ V. NOVAK, 1999, 48.
} 
samo na prakticiranje u obiteljskim krugovima jer je u službenoj uporabi jezik bio sustavno zatiran. Upravo su obitelji kao osnovni činitelj svakog društva osigurale očuvanje jezika u narednim godinama.

\section{Povijesna utemeljenost likova}

Nakon povijesnoga uvoda, nužnoga kako bi se rad smjestio u prostor i vrijeme, središnji predmet razmatranja rada je povijesna utemeljenost likova. Iako se radi o književnom djelu, jasno je da Novak želi prikazati povijesnu sliku Senja. Uostalom, zato ga i književni povjesničari nazivaju povijesnim romanom, ali i socijalnim te obiteljskim romanom.

Stoga je posve opravdano zapitati se jesu su likovi uistinu postojali u povijesti Senja? Jedna od temeljnih premisa književnoga djela je da s Jurjem Stipančićem koji je promijenio prezime, ${ }^{18}$ što se može tumačiti i kao simbolička smrt, ${ }^{19}$ nestaje i zauvijek se gasi loza Stipančića. Analiza će stoga započeti upravo s najistaknutijom obitelji u književnom djelu - Stipančićima, nakon čega slijede i ostali povijesni akteri, nositelji radnje u ovome romanu.

\section{Stipančići}

\section{a) Dorothea Stipančić}

Prema podacima koji su dokumentirani u sustavu Family search, ${ }^{20}$ utvrđeno je postojanje Dorothee Stipančić. Iako nema podataka o njezinoj lozi i roditeljima, prema crkvenim knjigama rođena je u Senju 1834., u razdoblju koje vremenski odgovara radnji romana.

Dorothea Stipančić vjenčala se s Josephusom Kozmaćem koji je također rođen 1834. godine. Nažalost, podatka o točnom datumu vjenčanja nema, ali postoji zapis o dvjema kćerima Heleni i Rosaliji. Vjenčanjem s J. Kozmaćem D. Stipančić prihvatila je prezime Kozmać, čime završava prezime Stipančić u ovoj lozi jer obje kćeri nose prezime Kozmać (iako Helena nosi prezime u kojem je "z" zamijenjeno sa "ž".) No, kako u cijeloj lozi prezime glasi "Kozmać", a ne "Kožmać" za pretpostaviti je da se radi o grešci pri upisu ili pri prijepisu.

\footnotetext{
${ }^{18}$ V. NOVAK, 1999, 91.

${ }^{19}$ D. DURIĆ, 2011, 35.

${ }^{20}$ Family Search, URL: https://www.familysearch.org/en/ (2019-12-19)
} 


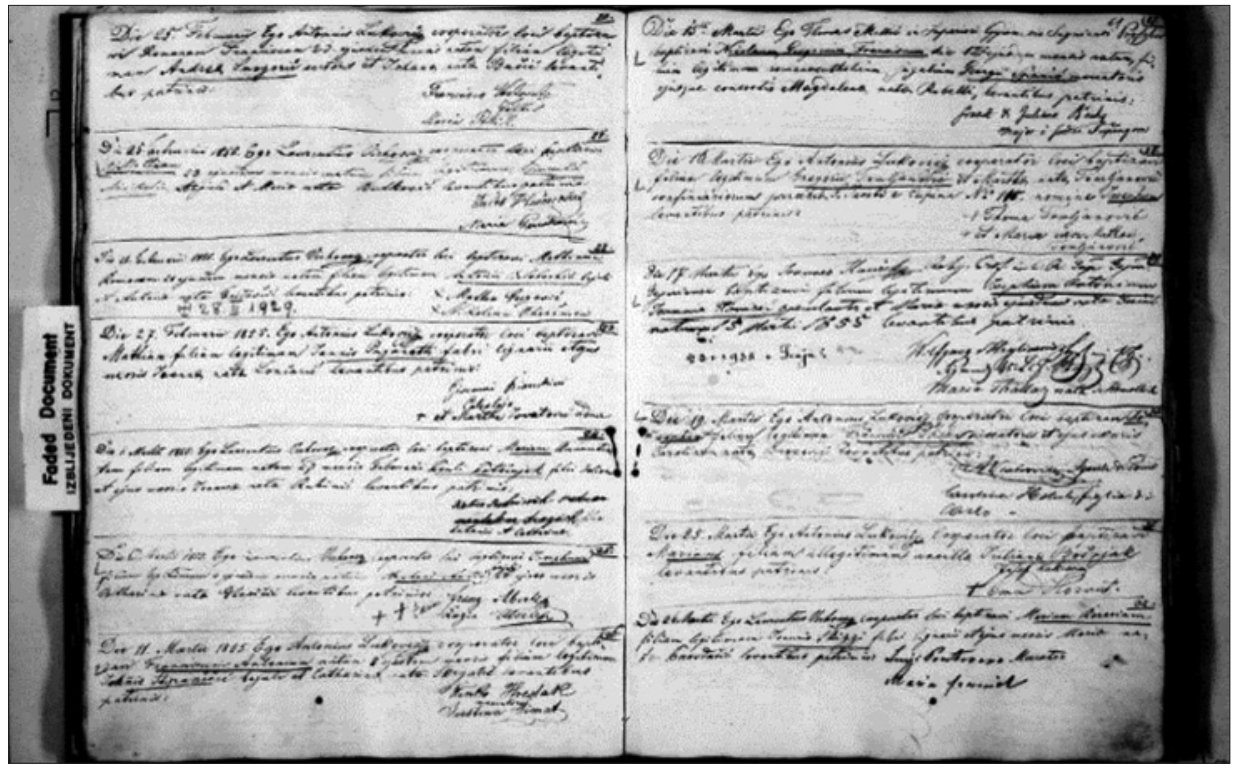

S1. 1. Franciscum Antonius Stipančić, rođen 1855., Senj, Matične knjige rimokatolika, Župa Senj, 1114., Matična knjiga rođenih, 1849. - 1858.

(izvor: Arhiv Hrvatske Zagreb, broj trake 289)

\section{b) Franciscum Antonius Stipančić}

Kako bi se dokazalo postojanje loze Stipančića u Senju, zanimljiviji su muški predstavnici koji nisu mijenjali prezime. Tako postaje jasno da je podatak iz djela, prema kojem je prezime Stipančić iščezlo iz grada u trenutku kada je Juraj promijenio ime u mađarsku verziju ${ }^{21}$, pogrešan. Naime, u Matičnim knjigama nalaze se upisi rođenih i umrlih u Senju između 1756. i 1858. godine. ${ }^{22} \mathrm{U}$ predmetnoj knjizi prvi je zabilježen upis rođenja Franciscuma Antoniusa Stipančića, koji je 1855. godine rođen u Senju. F. A. Stipančić bio je sin Ioknisa i Catharine.

\section{c) Lucam Stipančić}

Iz iste Matične knjige ${ }^{23}$ vidljivo je da je 1857. godine rođen Lucam Stipančić, sin Joannisa Stipančića i Katarine. Važno je pri tome uočiti

${ }^{21}$ György Istvánnfy.

${ }^{22}$ Matične knjige rimokatolika, Župa Senj, 1114., Matična knjiga rođenih, 1849. - 1858., Arhiv Hrvatske Zagreb (današnji HDA), broj trake 289.

${ }^{23}$ Ibid. 
sličnost između imena roditelja Franciscuma Antoniusa Stipančića, Ioknisa i Catharine, te roditelja Lucama Stipančića - Joannisa i Katarine. S vrlo velikom vjerojatnošću može se tvrditi da se radi o dvjema varijantama zapisa imena istih osoba. Dakle, može se zaključiti da su Franciscum Antonius i Lucam Stipančić bili braća. O njima, nažalost, nema dodatnih podataka. No, ovi podaci pokazuju mogućnost postojanja muške loze sredinom 19. st. u Senju koja je mogla nastaviti tradiciju prezimena.

\section{d) Laurentium Stipančić}

Laurentium Stipančić rođen je 1857. godine, također u Senju. Rođen je u obitelji oca Nicolaia i majke Mariae..$^{24} \mathrm{O}$ njima ne postoje daljnji podaci, no svakako je neobičan oblik imena koji se nalazi kod oca. Ono bi u hrvatskoj inačici glasilo "Nikola", no kako se i kod majke nalazi dvoglas "ae" umjesto "e" može se pretpostaviti da je očito onaj tko je upisivao podatak bio skloniji starim verzijama imena. Nažalost, još ne postoji jasna poveznica koja bi povezivala ova tri muška predstavnika obitelji Stipančić jer u arhivskom gradivu ne postoje genealoški podaci pomoću kojih bi se moglo utvrditi šire rodoslovno stablo. Stoga se može samo zaključiti da nisu bili povezani putem majki i očeva.

\section{Domazetovići}

Nakon Stipančića, Domazetovići su svakako jedni od važnijih sudionika koje Novak navodi u svojem djelu. Iako su Domazetovići poznata senjska plemenitaška obitelj, o čijoj povijesnoj utemeljenosti ne treba posebno raspravljati, ovaj rad dat će prilog poznavanju loze Domazetovića koristeći dva člana pronađena $u$ arhivskim izvorima.

\section{a) Franciska Domazetovich}

Franciska Domazetovich je, prema Matičnoj knjizi ${ }^{25}$ rođenih i umrlih, rođena u Senju 1763. godine, dakle negdje početkom odvijanja radnje romana. O F. Domazetovich nemamo više podataka osim onoga o rođenju, no svakako može poslužiti kao utemeljenje likova iz djela.

${ }^{24}$ Ibid.

${ }^{25}$ Matične knjige rimokatolika, Župa Senj, 1114., Matična knjiga rođenih, 1734. - 1775., Arhiv Hrvatske Zagreb (današnji HDA), broj trake 289. 


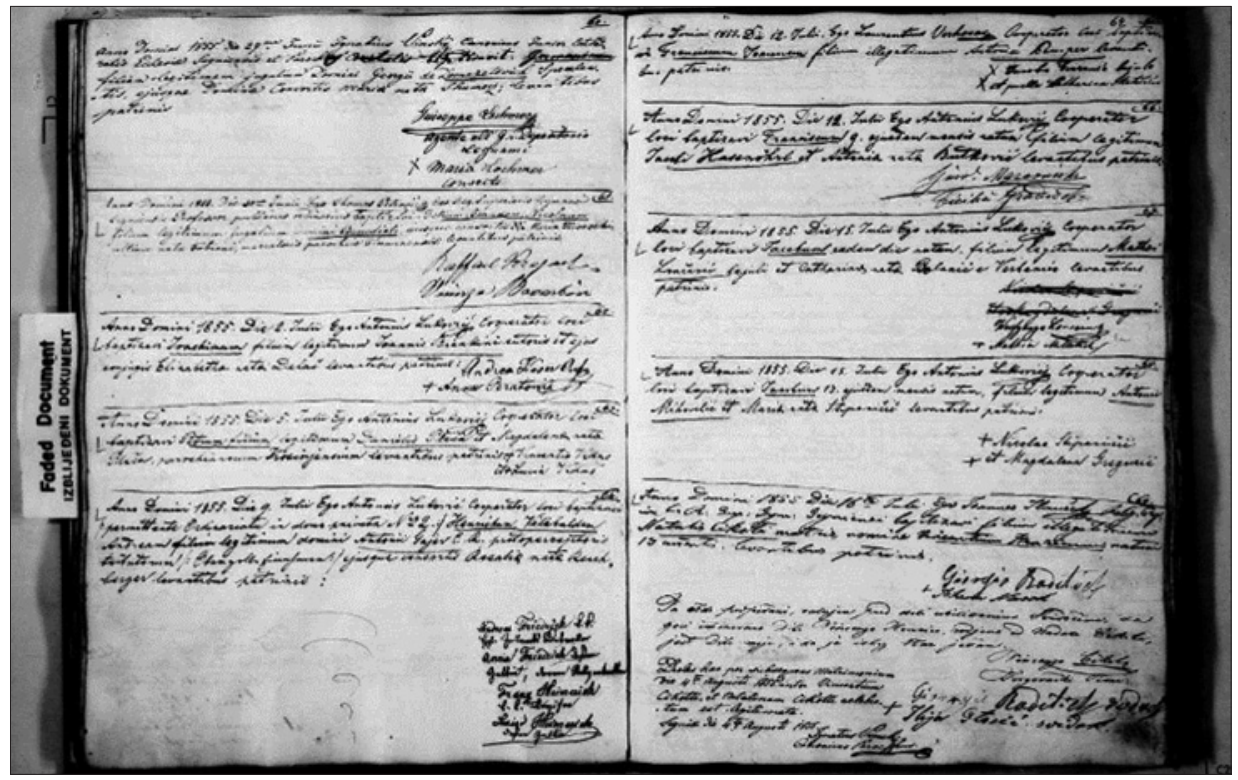

S1. 2. German de Domazetovich, rođ. 1855., Senj, Matične knjige rimokatolika, Župa Senj, 1114., 1849. - 1858. (izvor: Arhiv Hrvatske Zagreb, broj trake 289)

\section{b) German de Domazetovich}

German de Domazetovich rođen je u Senju 1855. godine. ${ }^{26}$ Otac G. de Domazetovicha bio je Georgü de Domazetovich, a majka Mariæ Shumecz. Kao i kod majke Laurentiuma Stipančića, zanimljivo je primijetiti dvoglase u imenu te prijeglas na slovu "u" u imenu oca. Enver Ljubović također primjećuje kako se prezime Domazetovića značajnije razlikuje u pojedinim slučajevima; tako se ponekad dodaje prefiks "de" ili se prezime završava na "ch". Ljubović upozorava i na činjenicu da se "D" na mjestu prvog slova prezimena može ponekad zamijeniti sa "T", no da i dalje takve obitelji valja razmatrati kao dio loze Domazetovića. ${ }^{27}$

\section{Biskup Juraj Vuk Čolić}

Biskup kojega spominje V. Novak posve je utemeljena povijesna ličnost, a poznat je još i kao Juraj (Vuk) Čolić: "A što ste ono, majko, bili spomenuli o biskupu Čoliću? To je bio velik čovjek - reče gospođa Valpurga pogledavši

${ }^{26}$ Matične knjige rimokatolika, Župa Senj, 1114., Matična knjiga rođenih, 1849. - 1858., Arhiv Hrvatske Zagreb (današnji HDA), broj trake 289.

${ }^{27}$ E. LJUBOVIĆ, 2009, 201. 
sa slavnim izrazom lica Luciju - velik čovjek, učen, pobožan i slavan! Bila je to obitelj senjskih patricija i plemića iz davnine, a on se pisao punim imenom: Juraj Vuk barun Čolić de Löwensburg". ${ }^{28}$ Čolić je bio senjski biskup čiji je grb sačuvan, a opisao ga je E. Ljubović. ${ }^{29}$

Povijesni sukob koji se navodi u djelu, a odnosi se na konflikt između biskupa i obitelji Domazetović, kada je biskup Čolić bio optužen da ima dijete s Anom Domazetović, povijesno je utemeljen..$^{30}$ Povijesno je također točan i odlazak biskupa u Rim jer se o aferi pročulo sve do pape. ${ }^{31}$ Važno je pritom naglasiti da se biskup nikada nije vratio iz Rima. O biskupu Čoliću saznajemo iz vizitacijskih pisama koje je pisao i to 1748., 1753. i 1757. godine, a koje je objavio Mile Bogović. ${ }^{32}$ Relevantno je pritom primijetiti da je biskup Čolić živio stoljeće prije nego se odvila radnja romana Posljednji Stipančići. Naime, on je rođen u Senju 1699., a biskupsku je službu obnašao od 1754. do 1764. ${ }^{33}$ Stoga, iako povijesna autentičnost postoji, nepobitna je i vremenska divergentnost.

\section{Filip Vukasović}

Filip Vukasović kojeg Novak spominje u funkciji vikara stolne crkve ${ }^{34}$ također je osoba koja je povijesno postojala. Vukasović je rođen 1759. godine u Senju. Obnašao je dužnost senjskog kanonika, a potom i generalnog vikara Senjske biskupije. U Senju je bio i župnik od 1798. do 1800. godine, a od 1806. do 1810. godine bio je rektor sjemeništa.

Bitno je razlikovati Filipa Vukasovića, vikara i Filipa Vukasovića, poznatog graditelja koji je rođen četiri godine prije. Smrću Josipa Filipa Vukasovića 1809. te njegova sina Filipa 1844. godine izumire i prezime Vukasović. Vikar Filip Vukasović umro je prije 1820. godine. ${ }^{35}$

\section{Upisnici čestica u Hrvatskom državnom arhivu u Zagrebu}

Budući da se u knjigama rođenih mogu iščitati informacije o rođenju i postojanju članova loze Stipančić sredinom 19. st., nameće se pitanje jesu li

\footnotetext{
${ }^{28}$ V. NOVAK, 1999, 10.

${ }^{29}$ E. LJUBOVIĆ, 2006, 80.

${ }^{30}$ M. BOGOVIĆ, 2015, 120.

${ }^{31}$ Ibid.

${ }^{32}$ M. BOGOVIĆ, 1996, 180-182.

${ }^{33}$ M. BOGOVIĆ, 2015, 119.

${ }^{34} \mathrm{~V}$. NOVAK, 1999, 14.

${ }^{35}$ E. LJUBOVIĆ, 2006, 63.
} 
u drugoj polovici 19. st. što posjedovali u Senju. Upravo su Upisnici čestica ${ }^{36}$ vrlo vrijedni dokumenti koji mogu pomoći u razmatranju ovih pitanja.

Upisnik odabran za analizu najbliži je godinama rođenja gore spomenutih članova obitelji - onaj iz 1870. godine, stoga bi bilo za očekivati da se u njemu nalaze podaci o posjedima Stipančića. No, u samome Upisniku ni na jednom se mjestu ne spominje obitelj Stipančić. Spominju se u njemu tradicionalna senjska prezimena poput Biondića i Nekića, no nema spomena pripadnika tražene loze.Takav podatak može se tumačiti dvojako. Posve je moguće da sve čestice nisu zavedene ili da je došlo do greške prilikom upisivanja. Druga mogućnost je da Stipančići koji su rođeni sredinom stoljeća nisu ostali u Senju ili barem nisu ostvarili prava na kakve posjede. Ako bi to bilo točno, navodi Vjenceslava Novaka o posljednjima Stipančićima tijekom prve polovice 19. st. dobili bi na dodatnoj vrijednosti.

U daljnjim istraživanjima, koja bi premašila opseg rada, ostaje vidjeti sačuvane Upisnike koji se nastavljaju 1874. i dalje te provjeriti postoji li spomen članova obitelji u nekim narednim godinama.

\section{Zaključak}

Rad je ponudio nekoliko zaključaka. Onaj primarni ukazuje na to da je roman pisan na iznimno dokumentaristički način, bilježi točne podatke o povijesnoj zbilji Senja toga vremena, uz određena manja odstupanja. No, takav zaključak bio je poznat i ranije te se dodatnim raspravama samo potvrdio; razvidno je da je Novak svojim opisima potpuno točno prenosio usud plemićkog staleža prve polovice 19. st. u malenim mjestima kao što je to bio Senj, upotpunjujući svoje opise i određenim egzaktnim informacijama.

Iz arhivskoga se gradiva, pak, može zaključiti da su tijekom prve polovice 19. st. rođeni novi pripadnici loze Stipančić, čemu naravno treba pristupiti cum grano salis jer to ne znači da su oni bili u srodstvu ili povezani sa Stipančićima koje Novak opisuje (ako se pretpostavi da su navedeni Stipančići bili povijesne ličnosti iako za njih ne postoji arhivsko-dokumentacijska osnovica). Ipak, takvo otkriće ukazuje na činjenicu da su navedeni pripadnici loze rođeni i vjerojatno živjeli u Senju tijekom perioda koji se u završetku romana, što je pokazatelj da su Stipančići kao loza ostali i nešto duže u Senju. Navedenim tezama, pak, valja dodati i otkriće da se u Upisnicima čestica iz 1870. ne pronalaze posjedi obitelji Stipančić te bi takva činjenica ukazala da su u razdoblju od

${ }^{36}$ Upisnik zemljišnih i kućnih čestica, 1870., Sig. HR-HDA-1421-1-3-120-2-1. 
20-tak godina oni uistinu iščeznuli iz Senja. Drugi likovi koji se navode u romanu, točnije njihove loze, posve su povijesno utemeljeni, kao npr. obitelj Domazetović. Ono što je vrlo zanimljivo je da je jedini lik prenesen u cijelosti upravo lik biskupa Čolića, što otvara pitanje poruke autora samoga djela.

$\mathrm{Na} \mathrm{koncu,} \mathrm{ovaj} \mathrm{rad} \mathrm{zatvara} \mathrm{jedno} \mathrm{poglavlje} \mathrm{istraživanja} \mathrm{loze} \mathrm{plemićkih}$ obitelji, no potencira i nova buduća samostalna istraživanja u genealoškom smislu, ali i vezano za imovinsko-pravne odnose toga vremena. Djelo Vjenceslava Novaka nesumnjivo ostaje trajnom inspiracijom za buduća slična književna, ali i historiografska istraživanja.

\section{Literatura}

\section{Izvori}

Matične knjige rimokatolika, Župa Senj, 1114., Matična knjiga rođenih, 1734. -1775., Arhiv Hrvatske Zagreb, broj trake 289.

Matične knjige rimokatolika, Župa Senj, 1114., Matična knjiga rođenih, 1849. -1858., Arhiv Hrvatske Zagreb, broj trake 289.

Vjenceslav NOVAK, Posljednji Stipančići, Bulaja naklada, Zagreb, 1999.

Upisnik zemljišnih i kućnih čestica, 1870., Sig. HR-HDA-1421-1-3-120-2-1

\section{Knjige i članci}

Željko BARTULOVIĆ, Neka pitanja iz povijesti Senja, Senjski zbornik, 34, Senj, 2007, 265-296.

Mile BOGOVIĆ, Sadržaj izvješća senjsko-modruških biskupa u Rim od 1602. do 1919. godine, Senjski zbornik, 23, Senj, 1996, 161-196.

Mile BOGOVIĆ, Moji predšasnici biskupi - u Senju, Otočcu, Krbavi, Modrušu, Vinodolu i Rijeci, Senjski zbornik, 42-43, Senj, 2015-2016, 5-198.

Dejan DURIĆ, Autoritet i obitelj u romanu Posljednji Stipančići Vjenceslava Novaka, Kroatologija, 2, Zagreb, 2011, 19-41.

Enver LJUBOVIĆ, Senjski uskoci i plemići Vukasovići i njihovi grbovi, Senjski zbornik, 33, Senj, 2006, 63-78.

Enver LJUBOVIĆ, Senjski uskoci i plemići Čolići i njihovi grbovi, Senjski zbornik, 33, Senj, 2006, 79-90.

Enver LJUBOVIĆ, Senjska uskočka i plemićka obitelj Domazetović i njihovi grbovi, Senjski zbornik, 36, Senj, 2009, 199-208.

III. Internetski izvori

Family Search, URL: https://www.familysearch.org/en/ (2019-12-19) 
SENJ, Hrvatska online enciklopedija, URL: https://www.enciklopedija.hr/natuknica. aspx?ID=55414 (2019-12-19)

SENJ, Povijest Grada, URL: https://www.senj.hr/povijest-grada/ (2020-7-6)

\section{THE DESCRIPTIONS OF THE CITY GENTRY IN THE NOVEL POSLJEDNJI STIPANČIĆI BY VJENCESLAV NOVAK AND THEIR HISTORICAL BASIS}

\section{Summary}

The paper takes the descriptions of the urban noble families from the novel Posljednji Stipančići (The Last Stipančićs) by Vjenceslav Novak as a starting point of its historiographical analysis. After a short historical framework is presented, which is supplemented by descriptions given by V. Novak, the paper also briefly looks at the issue of the struggle for the Croatian language, although it deals mostly with the analysis of the historical foundation of the characters and action using exact and precise quotations from actual historical reality. In the end, the Cadastral registers from the State Archives in Zagreb that are also compared with the statements cited in the work are presented.

Keywords: nobility, Senj, $19^{\text {th }}$ century, Vjenceslav Novak, the Stipančićs 